\title{
EFEKTIVITAS UNDANG-UNDANG NOMOR 8 TAHUN 1999 TENTANG PERLINDUNGAN KONSUMEN TERHADAP JUAL BELI DENGAN SISTEM TRANSAKSI ELEKTRONIK (E-COMMERCE)
}

\author{
Muhajir Akbar Hamsah \\ Mahasiswa Program Pascasarjana Universitas Muslim Indonesia Makassar \\ email :muhajirakham@gmail.com
}

\begin{abstract}
Legal protection to consumers by BPSK through means of mediation or conciliation or arbitration is made on the choice and consent of the parties concerned. Consumer dispute resolution is not a gradual dispute resolution process.

Factors affecting the process of providing legal protection to the sale and purchase through electronic transactions are legal factors that still weaken the parties, especially the consumer, the requirement of the agreement in Article 1320 of the Civil Code can not be fulfilled in full, especially the matter of proficiency. The activities of the cyberspace can not be approached by conventional law size and classification alone, because if this method is taken too much difficulty and passes the enforcement of the law.
\end{abstract}

Keywords: Consumer Protection; Purchase; Electronic Transaction;

\section{Abstrak}

Perlindungan hukum kepada konsumen oleh BPSK melalui mediasi atau konsiliasi atau arbitrasi dilakukan berdasarkan pilihan dan persetujuan dari pihak-pihak terkait. Resolusi perselisihan konsumen bukanlah proses penyelesaian perselisihan bertahap.

Faktor-faktor yang mempengaruhi proses pemberian perlindungan hukum terhadap jual beli melalui transaksi elektronik adalah faktor hukum yang masih melemahkan para pihak, terutama konsumen, persyaratan perjanjian dalam Pasal 1320 KUHPerdata tidak dapat dipenuhi secara penuh, terutama soal kemahiran. Kegiatan dunia maya tidak dapat didekati dengan ukuran hukum konvensional dan klasifikasi saja, karena jika metode ini diambil terlalu banyak kesulitan dan melewati penegakan hukum.

Kata kunci: Perlindungan Konsumen; Pembelian; Transaksi Elektronik;

\section{A. PENGANTAR}

Konsumen dalam transaksi e-commerce memiliki resiko yang lebih besar daripada penjual, seperti barang yang telah dibeli tidak sesuai pesanan, atau barang tersebut tidak dikirim oleh penjual. Karena itu, selain jaminan yang diberikan oleh penjual diperlukan juga jaminan yang berasal dari pemeritah. Pemerintah sudah mengeluarkan Undang-Undang Nomor 8 Tahun 1999 tentang Perlindungan Konsumen dan Undang-Undang Nomor 19 Tahun 2016 sebagaimana perubahan atas Undang-Undang Nomor 11 Tahun 2008 tentang Informasi dan Transaksi Elektronik, tapi pelaksanaannya kurang efektif, sehingga perlindungan untuk konsumen masih kurang 
terjamin.Konsumen butuh perlindungan hukum, yaitu suatu perlindungan yang diberikan terhadap subyek hukum dalam bentuk perangkat hukum baik yang bersifat preventif maupun bersifat represif.

Selanjutnya menyangkut penyelesian hukum jika terjadi sengketa antara pihak yang melakukan jual beli melalui media internet tersebut. Persoalan tersebut, akan menjadi rumit, jika para pihak berada dalam wilayah negara yang berbeda, menganut sistem hukum yang berbeda pula. Hal ini biasa terjadi karena mengingat internet merupakan dunia maya yang tidak mengenal batas-batas kenegaraan, dan dapat diakses dari bebagai belahan dunia manapun selama masih terdapat jaringan internet.

Indonesia sebagai bagian dari masyakarat internasional, juga turut mengatur praktik kontrak elektronik ini dalam Undang-Undang Nomor 19 Tahun 2016 sebagaimana perubahan atas Undang-Undang Nomor 11 Tahun 2008 tentang Informasi dan Transaksi Elektronik, khususnya dalam keberadaan Pasal 18 dengan tujuan dapat menjembatani adanya kesenjangan (gap) antara hambatan teknologi dan memenuhi nilai perlindungan hukum dalam praktik penyelesaian sengketa transaksi elektronik.

Ironisnya dari beberapa kasus-kasus sengketa kontrak elektronik yang terjadi di Indonesia, keberadaan Pasal 18 Undang-Undang Nomor 19 Tahun 2016 sebagaimana perubahan atas Undang-Undang Nomor 11 Tahun 2008 tentang Informasi dan Transaksi Elektronik bukan menjadi upaya yang ditempuh dalam menyelesaikan sengketa yang ada, dan cara-cara penyelesaian sengketa secara konvensional yang kurang tepat sasaran menjadi pilihan. Cara penyelesaian sengketa konvensional ini juga seringkali dihadapkan pada apatisme dan persoalan harga jenis barang yang menjadi objek sengketa dan biaya pengurusan konsultasi hukum dan mekanisme penyelesaian sengketa yang berbanding terbalik, memicu rendahnya minat konsumen.

Perlindungan atas kepentingan konsumen diperlukan, mengingat bahwa dalam kenyataannya pada umumnya konsumen selalu berada di pihak yang dirugikan. Begitu banyak yang dapat dibaca berita-berita yang mengungkapkan perbuatan curang produsen yang menimbulkan kerugian bagi konsumen, seperti berita tentang biskuit beracun, makanan yang kadaluwarsa, dan sebagainya yang menimbulkan kerugian materiil maupun moril bagi konsumen.

Perlindungan konsumen mempunyai dua aspek yang bermuara pada praktik perdagangan yang tidak jujur (unfair trade practices), dan masalah keterkaitan pada syarat-syarat umum dalam suatu perjanjian. Perlindungan pada aspek pertama mencakup perlindungan terhadap timbulnya kerugian bagi konsumen karena memakai atau mengonsumsi barang yang tidak sesuai dengan yang diinginkan oleh konsumen. Pada aspek kedua, mencakup perlindungan terhadap diberlakukannya syarat-syarat yang tidak adil bagi produsen/pelaku usaha kepada konsumen pada waktu mendapatkan barang kebutuhannya, misalnya mengenai harga, biaya untuk menyelenggarakan perjanjian (kontrak), dan sebagainya baik sebagai akibat dari penggunaan standar kontrak maupun karena perilaku curang dari produsen. 


\section{B. ANALISIS DAN PEMBAHASAN}

\section{Perlindungan Terhadap Konsumen}

Istilah konsumen berasal dari alih bahasa dari kata consumer (InggrisAmerika), atau consument/konsument (Belanda). Pengertian dari consumer atau consument itu tergantung dalam posisi mana ia berada. Secara harafiah arti kata consumer adalah (lawan dari produsen) setiap orang yang menggunakan barang. Tujuan penggunaan barang atau jasa nanti menentukan termasuk konsumen kelompok mana pengguna tersebut. Begitu pula Kamus Bahasa Inggris - Indonesia memberi arti kata consumer sebagai pemakai atau konsumen.

Konsumen umumnya diartikan sebagai pemakai terakhir dari produk yang diserahkan kepada mereka oleh pengusaha, yaitu setiaporang yang mendapatkan barang untuk dipakai dan tidak untuk diperdagangkan atau diperjualbelikan lagi. Menurut Pasal 1 angka 2 Undang-undang Nomor 8 Tahun 1999 bahwa Konsumen adalah setiap orang pemakai barang dan/atau jasa yang tersedia dalam masyarakat, baik bagi kepentingan diri sendiri, keluarga, orang lain, maupun makhluk hidup lain dan tidak untuk diperdagangkan. Sedangkan dalam Penjelasan Pasal 1 angka 2 UU No. 8 Tahun 1999 bahwa konsumen yang dimaksud adalah konsumen akhir yang dikenal dalam kepustakaan ekonomi.

Peraturan perundang-undangan negara lain, memberikan berbagai perbandingan tentang arti kata konsumen. Umumnya dibedakan antara konsumen antara dan konsumen akhir. Dalam merumuskannya, ada yang secara tegas mendefinisikannya dalam ketentuan umum perundangundangan tertentu, ada pula yang termuat dalam pasal tertentu bersamasama dengan pengaturan sesuatu bentuk hubungan hukum.

Ada beberapa batasan tentang konsumen, yakni:

a. Konsumen adalah setiap orang yang mendapatkan barang atau jasa digunakan untuk tujuan tertentu;

b. Konsumen antara adalah setiap orang yang mendapatkan barang atau jasa untuk digunakan dengan tujuan membuat barang atau jasa lain atau untuk diperdagangkan (tujuan komersial);

c. Konsumen akhir adalah setiap orang alami yang mendapat dan menggunakan barang dan atau jasa untuk tujuan memenuhi kebutuhan hidupnya pribadi, keluarga dan atau rumah tangga dan tidak untuk diperdagangkan kembali (non komersil).

Dengan demikian, dapat dikatakan bahwa semua orang adalah konsumen karena membutuhkan barang dan jasa untuk mempertahankan hidupnya sendiri, keluarganya, ataupun untuk memelihara/merawat harta bendanya.

Undang-undang Nomor 8 Tahun 1999 tentang Perlindungan Konsumen memungkinkan penyelesaian sengketa konsumen di luar pengadilan, yang dilaksanakan untuk mencapai kesepakatan mengenai bentuk dan besarnya ganti kerugian dan/atau mengenai tindakan tertentu untuk menjamin tidak 
akan terjadi kembali, atau tidak akan terulang kembali kerugian yang diderita oleh konsumen (Pasal 47).

Untuk membantu penyelesaian sengketa konsumen di luar pengadilan, dilakukan melalui Badan Penyelesaian Sengketa Konsumen (BPSK). Badan ini merupakan badan hasil bentukan pemerintah yang berkedudukan di ibukota Daerah Kabupaten/Kota (Pasal 49 ayat 1).Penyelesaian sengketa konsumen di luar pengadilan ini dilakukan dengan jalan mediasi, arbitrase, atau konsiliasi. Jadi, majelis BPSK sedapat mungkin mengusahakan terciptanya kesepakatan diantara pihak-pihak yang bersengketa, sebagai bentuk penyelesaian sengketa tersebut.

Tugas dan wewenang BPSK menurut Pasal 52 UU No. 8 Tahun 1999 tentang Perlindungan Konsumen, adalah:

a. Melaksanakan penanganan dan penyelesaian sengketa konsumen, dengan cara melalui mediasi atau arbitrase atau konsiliasi.

b. Memberikan konsultasi perlindungan konsumen

c. Melakukan pengawasan terhadap pencantuman klausula baku.

d. Menerima pengaduan, baik tertulis maupun tidak tertulis dari konsumen tentang terjadinya pelanggaran terhadap perlindungan konsumen.

Idealnya BPSK ini adalah sebuah lembaga arbitrase yang tugastugasnya berada pada lingkup mencari pemecahan/penyelesaian dengan jalan damai terhadap sengketa konsumen dengan produsen/pelaku usaha. Diharapkan dengan penyelesaian sengketa yang sederhana dan singkat, tidak diperlukan lagi penyelesaian sengketa melalui pengadilan yang cenderung lama dan berbelit-belit.Akan tetapi, UU No. 8 Tahun 1999 tentang Perlindungan Konsumen menentukan bahwa pemeriksaan perkara konsumen oleh BPSK bukan dengan jalan damai, melainkan didasarkan pada ketentuan hukum yang berlaku. Karena itu, majelis BPSK akan berusaha menemukan bukti-bukti tentang adanya pelanggaran hukum di dalam sengketa konsumen tersebut, dan membuat putusan sesuai dengan ketentuan hukum.

\section{Perjanjian Kontrak}

Kontrak pada dasarnya merupakan undang-undang yang mengikat dan memiliki konsekuensi hukum bagi para pihak. Dengan demikian, maka unsurunsur yang tercantum dalam hukum kontrak, adalahsebagai berikut :

\section{a. Adanya Kaidah Hukum}

Kaidah dalam hukum kontrak dibagi menjadi 2 (dua) bagian : tertulis dan tidak tertulis. Kontrak hukum yang tertulis, adalah kontrak kaidahkaidah hukum yang terdapat di dalam peraturan perundang-undangan, traktat, dan yurisprudensi. Sedangkan kaidah hukum kontrak tidak tertulis, adalah kaidah-kaidah hukum yang timbul, tumbuh, dan hidup dalam mesyarakat (hukum adat).

b. Adanya Subjek Hukum

Subjek hukum (rechtsperson), diartikan sebagai pendukung hak dan 
kewajiban. Subjek hukum dalam hukum kontrak, adalah kreditur dan debitur. Kreditur adalah orang yang berpiutang, sedangkan debitur adalah orang yang berutang.

c. Adanya Prestasi ( Objek Hukum )

Prestasi merupakan hak kreditur dan menjadi kewajiban bagi debitur. Prestasi menurut Pasal $1234 \mathrm{KUH}$ Perdata terdiri dari :memberikan sesuatu, berbuat sesuatu, dantidak berbuat sesuatu.

d. Kata Sepakat

Di dalam Pasal 1320 KUH Perdata ditentukan 4 (empat) syarat sahnya suatu perjanjian.Salah satunya adalah kata sepakat (konsensus). Kesepakatan adalah persesuaian pernyataan kehendak antara para pihak.

e. Akibat Hukum

Setiap perjanjian yang dibuat oleh para pihak, akan menimbulkan akibat hukum, yaitu timbulnya hak sebagai suatu kenikmatan dan kewajiban sebagai suatu beban.

Dalam kaitan ini, berkenaan dengan asas-asas perjanjian terdapat 5 (lima) asas penting dalam suatu perjanjian, yaitu :

1. Asas Kebebasan Berkontrak, memberikan kebebasan kepada para pihak untuk:

a. membuat atau tidak membuat perjanjian

b. mengadakan perjanjian dengan siapapun

c. menentukan isi perjanjian dengan siapapun

d. menentukan bentuknya perjanjian, yaitu tertulis atau lisan.

2. Asas Konsensualisme, dalam Pasal 1320 ayat (1) KUH Perdataditentukan bahwa salah satu syarat sahnya perjanjian, yaitu adanya kesepakatan kedua belah pihak. Asas konsensualisme pada umumnya tidak diadakan secara formal, tetapi cukup dengan adanya kesepakatan kedua belah pihak, atau persesuaian antara kehendak dan pernyataan yang dibuat oleh kedua belah pihak.

3. Asas Pacta Sunt Servanda, merupakan asas kepastian hukum sebagai akibat perjanjian. Asas ini diatur dalam Pasal 1338 ayat (1) KUH Perdata yang berbunyi : "Perjanjian yang dibuat secara sah berlaku sebagai undang-undang" Selain itu, asas ini bermakna bahwa pihak lain (hakim atau pihak ketiga) harus menghormati, dan tidak boleh mengintervensi substansi kontrak yang dibuat para pihak, sebagaimana layaknya sebuah undangundang.

\section{Asas Itikat Baik (Goede Trouw)}

Asas ini dimuat dalam Pasal 1338 ayat (3) KUH Perdata yang berbunyi : "Perjanjian harus dilaksanakan dengan itikat baik". Asas itikat baik ini merupakan asas para pihak, yaitu pihak kreditur dan debitur harus melaksanakan substansi kontrak berdasarkan kepercayaan atau 
keyakinan yang teguh, atau kemauan yang baik dari para pihak. Asas itikat baik ini dibagi 2 (dua) : itikat baik nisbi, dimana orang memperhatikan tingkah laku nyata orang atau subjek. Sedangkan itikat baik mutlak, penilaiannya terletak pada akal sehat dan keadilan, dan penilaian keadaan yang dibuat dengan ukuran objektif (penilaian yang tidak memihak) menurut norma-norma yang objektif.

\section{Asas Kepribadian (Personalitas)}

Asas ini merupakan asas yang menentukan bahwa seseorang akan melakukan, atau membuat kontrak hanya untuk kepentingan perseorangan saja, sebagaimana dalam Pasal $1315 \mathrm{KUH}$ Perdata yang berbunyi : "Pada umumnya seseorang tidak dapat mengadakan perikatan atau perjanjian selain untuk dirinya sendiri", dan Pasal 1340 KUH Perdata yang menyatakan bahwa : "Perjanjian hanya berlaku antara pihak yang membuatnya". Namun ketentuan ini, ada pengecualiannya sebagaimana dalam Pasal 1317 KUH Perdata, yang menyatakan : "Dapat pula perjanjian diadakan untuk kepentingan pihak ketiga, bila suatu perjanjian yang dibuat untuk diri sendiri, atau suatu pemberian kepadaorang lain, mengandung suatu syarat semacam itu". Pasal ini mengkonstruksikan bahwa seseorang dapat mengadakan perjanjian untuk kepentingan pihak ketiga. Sedangkan dalam Pasal 1318 KUH Perdata, tidak hanya mengatur perjanjian untuk diri sendiri, tetapi juga untuk kepentingan ahli warisnya dan untuk orang- orang yang memperoleh hak dari padanya.

Jika dibandingkan, maka dalam Pasal 1317 KUH Perdatamengatur perjanjian untuk pihak ketiga, sedangkan dalam Pasal $1318 \mathrm{KUH}$ Perdata untuk kepentingan : (a) diri sendiri, (b) ahli warisnya, dan (c) orang-orang yang memperoleh hak dari padanya. Selain itu Pasal 1317 KUH Perdata mengatur tentang pengecualiannya, sedangkan Pasal $1318 \mathrm{KUH}$ Perdata tentang ruang lingkupnya yang luas.Disamping itu, menurut Mariam D.B, terdapat 8 (delapan) asas hukum perikatan nasional, yaitu : (a) asas kepercayaan, (b) asas persamaan hukum, (c) asas keseimbangan, (d) asas kepastian hukum, (e) asas moral, (f) asas kepatutan, (g) asas kebiasaan, (h) asas perlindungan. Dari semua penjelasan tentang asas-asas perjanjian, maka asas-asas yang ada saling melengkapi, dan dijadikan dasar pijakan para pihak dalam menentukan dan membuat kontrak.

\section{Penggunaan E-commerce}

Dalam Pasal 1 ayat (2) UU ITE dirumuskan pengertian Transaksi Elektronik sebagai perbuatan hukum yang dilakukan dengan menggunakan Komputer, jaringan Komputer, dan/atau media elektronik lainnya. Dalam era industri yang diikuti dengan kemajuan perdagangan, telah diikuti dengan hukum dagang yang mengatur transaksi dagang pada tingkat nasional maupun global. Hukum dagang mengatur bagaimana perjanjian dagang dibuat secara sah agar ditaati oleh para pihak yang membuatnya.

Sistem perdagangan dengan memanfaatkan sarana internet (interconnection networking), yang selanjutnya disebut e-commerce telah mengubah wajah dunia bisnis di Indonesia. Selain disebabkan oleh adanya perkembangan teknologi informasi, e-commerce lahir atas tuntutan 
masyarakat terhadap pelayanan yang serba cepat, mudah dan praktis. Melalui internet, masyarakat memiliki ruang gerak yang lebih luas dalam memilih produk (barang dan jasa) yang akan dipergunakan tentunya dengan berbagai kualitas dan kuantitas sesuai dengan yang diinginkan.

E-commerce merupakan salah satu bentuk transaksi perdagangan yang paling banyak dipengaruhi oleh perkembangan teknologi informasi. Melalui transaksi perdagangan ini, konsep pasar tradisional (dimana penjual dan pembeli secara fisik bertemu) berubah menjadi konsep telemarketing (perdagangan jarak jauh dengan menggunakan internet). E-commerce pun telah mengubah cara konsumen dalam memperoleh produk yang diinginkan.

\section{PENUTUP}

Berdasarkan analisis dan pembahasan berkenaan dengan perlindungan konsumen dari kemungkinan timbulnya kerugian karena penggunaannya, maka hukum perlindungan konsumen dapat dikatakan sebagai hukum yang mengatur tentang pemberian perlindungan kepada konsumen dalam rangka pemenuhan kebutuhannya sebagai konsumen.

Dalam menyelesaikan sengketa ganti kerugian di luar pengadilan dilakukan dengan melalui Badan Penyelesaian Sengketa, yaitu prosedur yang cepat, menghemat waktu dan biaya dalam menyelesaikan perkara, dapat memelihara hubungan antara konsumen dan pelaku usaha/produsen, tingginya kemungkinan untuk melaksanakan kesepakatan, kontrol dan lebih mudah memperlihatkan hasil, serta keputusan yang dapat bertahan sepanjang waktu.

\section{DAFTAR PUSTAKA}

Aswari, A. 2018. Peran Ganda Administrator sebagai Mediator dalam Sengketa Transaksi Ponsel Bekas secara Online. Jurnal Ilmiah Kebijakan Hukum, 12(3), 259-274.

Ahmadi Miru, Sutarman Yodo. 2004 Hukum Perlindungan Konsumen. Raja Grafindo Persada. Jakarta.

Ahmad Jayadi, Cahyana. 2008. Seputar Undang-Undang No. 11 Tahun 2008 Tentang Informasi dan Transaksi Elektronik (UU ITE) (Buku Panduan untuk memahami UU No. 11 Tahun 2008 Tentang Informasi dan Transaksi Elektronik), diterbitkan oleh Kementerian Komunikasi dan Informatika Republik Indonesia (KOMINFO).

Indahingwati, A., Launtu, A., Tamsah, H., Firman, A., Putra, A. H. P. K., \& Aswari, A. 2019. How Digital Technology Driven Millennial Consumer Behaviour in Indonesia. 유통과학연구, 17(8), 25-34.

Arif Mansur, Dikdik M. dan Elisatris Gultom. 2005. Cyber Law (Aspek Hukum Teknologi Informasi). Bandung: Refrika Aditama. 
Asnawi, Haris Faulidi. 2004. Transaksi Bisnis E-Commerce Perspektif Islam. Yogyakarta: Magistra Insania Press.

Janus Sidabalok. Hukum Perlindungan Konsumen di Indonesia. Medan:PT Citra Aditya Bakti. 2009

Mansur, Disdik M. Arief dan Elisatris Gultom. Cyber Law: Aspek Hukum Teknologi Informasi. Bandung : Refika Aditama. 2005

Muttaqin, Azhar. Transaksi E-Commerce Dalam Tinjauan Hukum Islam, Malang Ip. Universitas Muhamadiyah. 2009

M. Arsyad Sanusi. E-Commerce: Hukum dan Solusinya. Bandung: PT Mizan Grafika. 2007

Undang-Undang Nomor 19 Tahun 2016 sebagaimana perubahan atas UndangUndang Nomor 11 Tahun 2008 tentang Informasi dan Transaksi Elektronik 